\title{
THE CONTRIBUTION OF EXPERIENCED ENTREPRENEURS TO THE DEVELOPMENT OF RURAL AREAS IN THE REPUBLIC OF MACEDONIA
}

\author{
Tošo Kostadinov \\ "Ss. Cyril and Methodius" University in Skopje, Institute of Animal Science, \\ Bul. Ilinden 92-a, Skopje, Skopje, Republic of Macedonia \\ tosokostadinov@gmail.com
}

\begin{abstract}
The aim of this labor is to investigate the differences in terms of the attitudes towards the entrepreneurship between the experienced and the less experienced entrepreneurs from the rural areas in the Republic of Macedonia. For that purpose, a research survey has been made over a convenient sample of entrepreneurs (101 MSP), from the rural areas in the Republic of Macedonia. Around one third of the survey entrepreneurs, (32\%) have between 16 and 20 years of business experience, $23 \%$ of them are with commercial experience between 11 and 15 years and after them are those with the experience from 6 to 10 years with $(14 \%)$. Very close is also the number of the most experienced with more than 26 years functioning in the respective ambient - (13\%), while the group of 21-25 years, just like the one with the least experienced ( to 5 years ), is with an equal numerical representation $-9 \%$. The conclusion from the research made, claims that experienced entrepreneurs that enjoy more positive attitudes towards the entrepreneurship compared to the less experienced ones, contributes to the success of their firms and with it, an accelerated local economic development of the rural areas in the Republic of Macedonia.
\end{abstract}

Key words: entrepreneur; business experience; experienced entrepreneurs; less experienced entrepreneurs; rural areas

\section{ПРИДОНЕСОТ НА ИСКУСНИТЕ ПРЕТПРИЕМАЧИ ВРЗ РАЗВОЈОТ НА РУРАЛНИТЕ ПОДРАЧЈА ВО РЕПУБЛИКА МАКЕДОНИЈА}

\begin{abstract}
Целта на овој труд е да се истражат разликите во ставовите кон претприемништвото помеѓу искусните и помалку искусните претприемачи од руралните подрачја на Република Македонија. За таа цел спроведено е анкетно истражување врз пригоден примерок на претприемачи (101 МСП), од руралните подрачја на Република Македонија. Околу една третина од анкетираните претприемачи (32\%) имаат помеѓу 16 и 20 годишно искуство во бизнисот, 23\% од нив се со деловно искуство помеѓу 11 и 15 години, по што следуват оние со искуство од 6 до 10 години (14\%). Сличен е и бројот на оние најискусните - со повеќе од 26 години делување во предметниот амбиент - (13\%), додека групата од 21-25 години, како и онаа на најмалку искусните (до 5 години) е со еднаква бројна застапеност - 9\%. Од спроведеното истражување може да се заклучи дека искусните претприемачи имаат попозитивни ставови кон претприемништвото за разлика од помалку искусните претприемачи, што придонесува за успешноста на нивните претпријатија и со тоа и забрзан локален економски развој на руралните подрачја на Република Македонија.
\end{abstract}

Клучни зборови: претприемач; бизнис-искуство; искусни претприемачи; помалку искусни претприемачи; рурални подрачја

\section{INTRODUCTION}

Business experience is the experience that an individual gains on his workplace, through the job he performs. That is a factor of the entrepreneurial behavior and it can be studied from two points of views:

1. The dissatisfaction from the previous employment increases the opportunity for establishing a firm on your own.
2. Previous experience appeared as very serviceable. Most entrepreneurs start a job in the field that they have already been employed.

Although not the only one, the results from the empirical research (Davidson \& Honing, 2003) still prove that the market experience of the workforce, managerial experience and the previous working experience are crucially incorporated with the entrepreneurial activity. The study based on the experience, helps in raising the level of the tacit' 
knowledge which is larger than the' explicit' knowledge (Nonaka \& Takeuchi, 1995). The samples of the good practices and the experience of the entrepreneurs contribute a lot to the level of entrepreneur's knowledge and with it, the very same success of the firm.

\section{MATERIAL AND METHOD}

The aim of this research is based on the basis of literature, documents, and especially based on analysis of a questioned convenient sample of entrepreneurs (101 MSP ), so that we can see the influence of the experience of the entrepreneurs over their attitudes towards the entrepreneurship in the rural areas. Around one third of the questioned entrepreneurs (32\%) have between 16 and 20 years of business experience, $23 \%$ of them have commercial experience between 11 and 15 years and after them are those with the experience from 6 to 10 years (14\%). Similarly, the number of the most experienced ones is with more than 26 years of functioning in the respective ambient - (13\%), while the group of 21-25 years just like the one with the least experience (to 5 years ) is with equal numerical representation $-9 \%$.

In the labor of his making, several methods have been used, that are common to be used in the economic analysis, above all the method of generalization and specialization, the method of induction and deduction, the method of statistic and the comparative method.

\section{RESULTS AND DISCUSSION}

In the survey research, three sets of displayed answers have been offered to the respondents, which are of major significance for the influence of experience of the respondents from the rural areas in the Republic of Macedonia, for their views towards the entrepreneurship that is valued on a fiveleveled scale, starting from 1 - unimportant to 5 priority (Table 1, $2 \& 3$ ).

Table 1

Accordance to the claims of an aspect in improving operations of competitive market position, compared with the years of experience in the business

\begin{tabular}{|c|c|c|c|c|c|c|c|}
\hline & \multicolumn{7}{|c|}{ Total number of years of personal business experience - grouped } \\
\hline & \multicolumn{7}{|c|}{ Average value } \\
\hline & to 5 & $\begin{array}{l}\text { from } \\
06 \text { to } 10\end{array}$ & $\begin{array}{l}\text { from } \\
11 \text { to } 15\end{array}$ & $\begin{array}{l}\text { from } \\
16 \text { to } 20\end{array}$ & $\begin{array}{l}\text { from } \\
21 \text { to } 25\end{array}$ & $\begin{array}{c}26 \text { and } \\
\text { more }\end{array}$ & Total \\
\hline Improvement of the quality of the product/services & 4,10 & 4,00 & 4,26 & 4,09 & 4,40 & 4,30 & 4,17 \\
\hline Improvement of the promotion of the products & 4,30 & 3,93 & 4,17 & 4,09 & 4,60 & 4,50 & 4,20 \\
\hline Getting certificates for the quality & 4,20 & 3,53 & 4,13 & 3,94 & 4,30 & 4,40 & 4,03 \\
\hline Expert- Consulting help & 2,90 & 3,20 & 3,78 & 3,50 & 3,50 & 3,50 & 3,46 \\
\hline Advancement and education in the area of entrepreneurship & 3,70 & 4,20 & 3,87 & 3,47 & 4,00 & 4,30 & 3,83 \\
\hline Advancement and education in the area of informatics & 4,00 & 4,07 & 3,83 & 3,56 & 4,30 & 4,20 & 3,88 \\
\hline Advancement and education in the area of management & 3,70 & 3,87 & 3,78 & 3,72 & 4,10 & 4,10 & 3,83 \\
\hline Advancement and education in the area of finance & 3,80 & 3,47 & 3,39 & 3,87 & 3,70 & 3,70 & 3,66 \\
\hline Advancement and education in the sales area & 3,90 & 3,73 & 3,78 & 4,09 & 3,90 & 3,70 & 3,89 \\
\hline Advancement and education in the area of marketing & 3,90 & 4,00 & 3,78 & 4,03 & 3,90 & 3,70 & 3,91 \\
\hline Advancement and education in the area of foreign languages & 3,40 & 3,27 & 3,35 & 3,50 & 3,60 & 3,00 & 3,38 \\
\hline $\begin{array}{l}\text { Association with firms from my sector with the goal of } \\
\text { performing together on the market }\end{array}$ & 2,60 & 3,27 & 3,74 & 3,41 & 3,10 & 3,60 & 3,37 \\
\hline Help from the developed programs by refundable means & 3,90 & 4,33 & 4,39 & 4,28 & 4,40 & 4,45 & 4,31 \\
\hline Help from the developed programs by favorable credits & 3,90 & 4,20 & 4,39 & 4,25 & 4,50 & 4,55 & 4,30 \\
\hline Help from the developed programs by guarantee funds & 3,00 & 3,53 & 4,09 & 3,75 & 4,10 & 4,18 & 3,80 \\
\hline
\end{tabular}

Source: own calculations 
In the group of questions which refers to what should be done for the enhancement of the competitive position on the market, compared to the experience in the business that the respondents have, experienced entrepreneurs compared to the less experienced entrepreneurs value several claims much more positively and those are : enhancement of the quality of the products/services; enhancement of the promotion of the products; gaining certificates for quality; expert- consulting help; proficiency and education in the field of entrepreneurship; association of the companies from my sector with the aim of a mutual performance on the market; the help from the developed programs by refundable means; help from the developed programs by credits and help of the developed programs by guarantee funds. Insignificant differences between the more experienced and the less experienced entrepreneurs can be noticed in the claims that refer to the need of proficiency in the area of informatics, management, sales, marketing and foreign language learning.

Taken generally, experienced entrepreneurs have much more positive attitudes considering this group of questions.

Table 2

Accordance of the claims from an aspect of the plans for the business in future, compared with the years of experience in the business.

\begin{tabular}{|c|c|c|c|c|c|c|c|}
\hline & \multicolumn{7}{|c|}{$\begin{array}{c}\text { Total years of personal business - experience - grouped } \\
\text { Average value }\end{array}$} \\
\hline & to 5 & $\begin{array}{l}\text { from } \\
06 \text { to } 10\end{array}$ & $\begin{array}{l}\text { from } \\
11 \text { to } 15\end{array}$ & $\begin{array}{l}\text { from } \\
16 \text { to } 20\end{array}$ & $\begin{array}{l}\text { from } \\
21 \text { to } 25\end{array}$ & $\begin{array}{c}26 \text { and } \\
\text { more }\end{array}$ & Total \\
\hline Adding of a new product or service & 3,60 & 4,13 & 4,27 & 3,97 & 3,90 & 4,55 & 4,08 \\
\hline Sales on a new market & 2,30 & 3,00 & 3,96 & 3,50 & 3,10 & 3,45 & 3,37 \\
\hline A research of new markets & 2,20 & 3,00 & 3,96 & 3,47 & 2,80 & 3,45 & 3,32 \\
\hline Finding new distributive channels & 2,80 & 3,20 & 4,18 & 3,81 & 3,30 & 3,45 & 3,61 \\
\hline Expansion of marketing and promotion & 3,70 & 3,73 & 4,04 & 3,72 & 3,90 & 4,27 & 3,87 \\
\hline Investment in new devices/machines & 2,50 & 4,00 & 4,26 & 3,47 & 3,80 & 3,73 & 3,69 \\
\hline Replacement of the current machines/devices & 2,40 & 4,00 & 4,35 & 3,47 & 3,80 & 4,00 & 3,73 \\
\hline Expansion of the current plants & 2,30 & 3,80 & 4,30 & 3,44 & 3,90 & 4,00 & 3,68 \\
\hline Redesign/new schedule of the current plants & 1,70 & 3,60 & 3,78 & 3,19 & 3,90 & 4,18 & 3,42 \\
\hline Looking for an additional financial capital & 3,50 & 3,87 & 4,22 & 3,91 & 3,90 & 3,82 & 3,92 \\
\hline Computerization of the current operations & 2,20 & 3,47 & 3,78 & 3,19 & 3,70 & 2,91 & 3,29 \\
\hline Update of computer systems & 2,20 & 3,20 & 3,83 & 3,41 & 4,00 & 3,09 & 3,38 \\
\hline Redesign of the working activities & 2,20 & 3,27 & 3,74 & 3,31 & 3,80 & 2,82 & 3,29 \\
\hline Expansion of the working activities & 3,00 & 3,53 & 4,13 & 3,78 & 4,00 & 3,82 & 3,77 \\
\hline Looking for professional or technical advices & 2,70 & 3,27 & 3,96 & 3,47 & 3,70 & 3,09 & 3,46 \\
\hline Additional arrangement of expert employees & 2,70 & 3,20 & 3,74 & 3,44 & 3,90 & 2,82 & 3,38 \\
\hline $\begin{array}{l}\text { Investment in training for the employees( in a different } \\
\text { place/not in the company itself) }\end{array}$ & 2,60 & 3,00 & 2,43 & 2,59 & 3,20 & 3,18 & 2,63 \\
\hline
\end{tabular}

Source: own calculations

The questions that refer to future business plans are evaluated more positively, speaking about business experience itself and regarding the experienced entrepreneurs compared to the less experienced entrepreneurs. In this, the claims are: adding a new product or services; sales on the new market, research of new markets; research of new distributional channels; expansion of marketing and promotion; investment in new machines/devices; replacement of the current ma- 
chines/devices; expansion of the current plants; redesign/new schedule of the current plants; looking for additional financial capital; computerization of the current operations; update of the computer systems, redesign of the working activities, expansion of the working activities; looking for professional or technical advices; additional arrangement for the expert employees and investment in training the employees (in a different place/ not in the company itself).

Table 3

Consent in accordance with the claims of the entrepreneurship, compared with the years of experience in the business

\begin{tabular}{|c|c|c|c|c|c|c|c|}
\hline & \multicolumn{7}{|c|}{$\begin{array}{l}\text { Total years of personal business - experience - grouped } \\
\text { Average value }\end{array}$} \\
\hline & to 5 & $\begin{array}{l}\text { from } \\
06 \text { to } 10\end{array}$ & $\begin{array}{l}\text { from } \\
11 \text { to } 15\end{array}$ & $\begin{array}{l}\text { from } \\
16 \text { to } 20\end{array}$ & $\begin{array}{l}\text { from } \\
21 \text { to } 25\end{array}$ & $\begin{array}{c}26 \text { and } \\
\text { more }\end{array}$ & Total \\
\hline My business is the most important activity in my life & 3,20 & 3,80 & 4,35 & 4,28 & 4,30 & 4,36 & 4,13 \\
\hline I would do whatever it takes so that my business is successful & 3,50 & 3,87 & 4,35 & 4,28 & 4,30 & 4,45 & 4,18 \\
\hline I am planning to sell the business someday & 2,80 & 2,13 & 1,96 & 2,25 & 2,00 & 1,82 & 2,15 \\
\hline $\begin{array}{l}\text { With the development of a successful business I want to make a } \\
\text { meaningful contribution for the community }\end{array}$ & 3,70 & 4,13 & 4,43 & 4,38 & 4,50 & 4,27 & 4,29 \\
\hline $\begin{array}{l}\text { I prefer having my own business rather than to earn a bigger salary for } \\
\text { other job }\end{array}$ & 3,50 & 3,93 & 4,50 & 4,44 & 4.40 & 4,55 & 4,28 \\
\hline $\begin{array}{l}\text { Running your own business is more important than having more time } \\
\text { for your family }\end{array}$ & 3,40 & 3,40 & 3,78 & 3,97 & 4,20 & 3,91 & 3,80 \\
\hline $\begin{array}{l}\text { I would like to have my own business more than a another promising } \\
\text { career }\end{array}$ & 3,40 & 3,40 & 4,30 & 4,28 & 4,40 & 4,27 & 4,08 \\
\hline $\begin{array}{l}\text { It is important to the entrepreneur to comprehend and accept the risk to } \\
\text { start and run a successful business }\end{array}$ & 3,60 & 3,73 & 4,35 & 4,47 & 4,30 & 4,73 & 4,26 \\
\hline In order to run my business I am ready to argue with my family & 3,00 & 3,13 & 3,65 & 4,19 & 4,00 & 3,55 & 3,70 \\
\hline $\begin{array}{l}\text { In order to provide capital for my business I would put my house under } \\
\text { mortgage }\end{array}$ & 2,30 & 3,27 & 3,74 & 3,66 & 3,20 & 4,45 & 3,52 \\
\hline $\begin{array}{l}\text { For the good of my business I would be ready to enjoy less security in } \\
\text { my family }\end{array}$ & 2,80 & 3,33 & 3,91 & 3,81 & 3,70 & 4,00 & 3,67 \\
\hline I run my business to continue the family tradition & 2,60 & 2,73 & 3,83 & 3,38 & 3,60 & 3,45 & 3,34 \\
\hline I run my business to contribute benefits for my relatives & 3,00 & 2,93 & 3,65 & 3,72 & 3,80 & 3,73 & 3,52 \\
\hline I run my business so that I can live in a place that my family wants & 2,70 & 2,73 & 3,78 & 3,75 & 3,60 & 3,55 & 3,47 \\
\hline $\begin{array}{l}\text { I run my business in order to improve the status and prestige of my } \\
\text { family }\end{array}$ & 3,20 & 3,73 & 4,04 & 4,25 & 4,40 & 4,09 & 4,02 \\
\hline $\begin{array}{l}\text { I run my business in order to have more flexibility in my personal } \\
\text { family life }\end{array}$ & 3,50 & 3,47 & 4,13 & 4,34 & 4,10 & 4,55 & 4,08 \\
\hline
\end{tabular}

Source: own calculations

In the set of questions that are meant for the attitudes of entrepreneurship, compared to the experience in the business that the respondents have, the experienced ones gave a higher grade to the claims such as: my business is the most important activity in my life; I would do whatever it takes so that my business is successful; with the development of a successful business I want to make a meaningful contribution for the community; I would prefer to have my own business rather than earning a bigger salary working for someone else; running your own business is more important than having more time for the family; I would prefer having my own business rather than having another promising career; it is important so that the entrepreneur comprehends and accepts the risk to 
start and run a successful business; in order to run my business I am ready to argue with my family; in order to provide capital for my business I would put my house under mortgage; I would be ready to enjoy less security for my family in order to run my business; I run my business in order to continue the family tradition; I run my business to contribute for the benefits of my relatives; I run my business to live in the place that my family wants to live ; I run my business in order to improve the status and prestige of my family and I run my business to have more flexibility in my personal and family life. All in one, the intention of experienced entrepreneurs to sell their business at the end is likely to happen.

\section{CONCLUSION}

Experienced entrepreneurs have a great contribution for the local economic development in the rural areas in the Republic of Macedonia. Their more positive attitudes towards the entrepreneurship differing from the less experienced entrepreneurs make their companies to show greater performances than those whose owners are less experienced.

One of the goals of the state policies and the local power should be to create a favorable business- ambient in the rural places so that it can enable attraction of the experienced entrepreneurs from the cities, who would build new companies or they would expand the boundaries of the already existing companies from the cities in the rural places. The same refers to the already retired entrepreneurs from the urban areas who want to spend their retired days in a more calm ambient than the city and with it, spread the entrepreneurship culture in the rural area. All in all, experienced entrepreneurs should be stimulated by the mentors to pass their precious experience to the less experienced entrepreneurs.

\section{REFERENCES:}

[1] Becker G. S. (1964): Human Capital. Chicago: University of Chicago Press.

[2] Bricklin D. (2001): Natural-Born Entrepreneur, Harvard Business, School Publishing Corporation.

[3] Davidson P. (2003): Honig B.: The Role of Social and Human Capital Among Nascent Entrepreneurs, Journal of Business Venturing, 18 (3).

[4] Drucker F. P. (1999): Management Challenges for $21^{\text {st }}$ Century, B. K. Harper Business.

[5] Edvinsson L., Melone M. S. (1997): Intellectual Capital, New York, NY: Harper Collins Publishers.

[6] Honig B. (1998): What Determines Succes: Examining the Human, Financial and Social Capital of Jamaican Micro entrepreneurs, Journal of Business Venturing, 13 (5).

[7] Lin S. (2001): Taxation, Human Capital Accumulation and Economic Growth, Japanese Economic Review, 52 (2).

[8] Nonaka, I., Takeuchi H. (1995): The Knowledge-Creating Company, New York: Oxford University Press. 